\title{
Geopolitics in Indian Ocean Region: Through the Indian Lens
}

\author{
Abhishek Yadav \\ Department of Political Science, Faculty of Social Science, University of Delhi, Delhi, India \\ Email address: \\ abhishek8816077502@gmail.com, imabhishek1998@icloud.com

\section{To cite this article:} \\ Abhishek Yadav. Geopolitics in Indian Ocean Region: Through the Indian Lens. International and Public Affairs. \\ Vol. 5, No. 1, 2021, pp. 40-43. doi: 10.11648/j.ipa.20210501.17
}

Received: March 22, 2021; Accepted: May 24, 2021; Published: May 31, 2021

\begin{abstract}
This paper attempt to analyse the dynamics of the changing relations between the countries in the Indian Ocean region. Globally, the Indian Ocean Region holds a very crucial place due to its geo strategic importance. The struggle for power and to get a better hold of the region through which the major portion of the world trade passes through, the power rivalry is at its zenith. As new relations and groups emerge, the old powers and relationship which dominated the region in the past are fading. The emergence of India and China as the new economic giants has entirely changed the power dynamics in the Indian Ocean region. The rivalry between America and China turned the situation more critical. The resurgence of the QUAD grouping in the recent times against the dominance of the china in the region is a very bold and critical step at this juncture of time when in the third decade of the 21 st century the world is grappling with a deadly coronavirus pandemic on one side and China trying to turn the 21 st century into the Chinese century on the other side. The warm and friendly relations between India and America also turned out as irritant for the china. The article diagnoses the interaction between different rising and fading superpowers in the backdrop of geopolitics in the Indian ocean.
\end{abstract}

Keywords: Indian Ocean, Power Rivalry, National Interest, Geopolitics, Hegemony

\section{Introduction}

"Wherever there's power, there's politics"

The above saying by Turkish writer Elif shafak seems becoming a truth when we look at the geopolitics of the Indian ocean region. Firstly, the word geopolitics is formed from two separate words where geo connotes the geography and politics refer to the political scenario in the particular geographical region [1]. In simple terms Geopolitics is simply the analysis of the geographic influences on power relationships in international relations. The word geopolitics was originally coined by the Swedish political scientist RUDOLF KJELLEN during the dawn of the 20th century and it was widely used in the period between the two world wars (1918-1939). The current scenario in the international relations where the old powers are being replaced by the new giants and where economic power is the new might, the Indian ocean is at the forefront to witness the change in the balance of power. Hans J. Morgenthau the neo- classical realist in his famous work "Politics Among Nations" gave six principles of political realism. The second principle states that the main signpost that helps the political realism to find its way through the landscape of international politics is the concept of national interest defined in terms of power. It aptly proves that there are no permanent friends or no permanent enemies in the international relations. So in this article we will attempt to analyse the new emerging power equations in the Indian ocean and how the geopolitics of Indian ocean will affect the Indian stakes at shore!

The national interest is predetermined by geopolitics or the history of a country.

Joseph Nye.

The Indian ocean in the current realm in international relations has become of critical importance. It has been a geopolitical theatre and a ground for power politics in the past.

The Indian Ocean Region comprises of the Indian ocean and the several countries bordering it which includes some major rising economic powers like India, Australia, UAE, Bangladesh and island countries like Seychelles, Madagascar, Mauritius etc. The region is home to around 2.5 billion people or one third of the population of our planet. 
Also its the third largest ocean in the world covering around $20 \%$ of the earth's water surface and the only ocean which is named after a country i.e. India. The region is plentiful in energy resources and minerals including uranium, nickel, cobalt, aluminium and also important reserve for oil and gas which are very crucial in running today's world cycle.

The Indian ocean region countries in the past were part of great gamble of imperialism and colonialism. Britain and France mainly made these countries their colonies and ruled them for years impoverishing them of their natural resources. These western colonial masters left deep impact on these countries through their culture, language, food habits, dressing style etc.

After the second world war and during the dawn of independence in Asia and African during the 1950's and 1960 's, several of these countries tasted the freedom. Many of them remained unstable and faced the military extremism even after the independence.

The Indian ocean region power rivalry is at very important juncture as the balance of power is changing due to the rise of china and India and declining hegemonic stand of america. As the old power hierarchies and relations changes, it becomes important for India to analyse its stakes in the region very cautiously. PM modi in 2015 visited three small but crucially important Indian ocean island states - Mauritius, Seychelles and srilanka where he highlighted the ancient cultural linkages and trade relations and coined the acronym "SAGAR" which refers to Security and growth for all in the region and unveiled India's strategic vision for Indian ocean.

\section{The Past}

India holds a important place in history of the Indian ocean. The Arabian sea and the Bay of Bengal were the two important junctures for the trade and commerce since the times of Sumer and Mohenjodaro. The Turk and Moghul conquerors of India who passed through Afghanistan's mountain passes were gradually assimilated into the country's political system [2]. However, they never fully grasped the maritime imperative, and as a result, they were unable to cope with a succession of European traders who came to develop hegemony over the ocean and its littoral. The Britishers were the last great hegemon until the 1960's when the they left the Suez canal and the baton was passed on to the united states during the cold war.

India is not a nation, nor a country. It is a subcontinent of nationalities.-Muhammad Ali Jinnah [3].

\subsection{The Dawn of Independence}

The independence also brought the partition of the subcontinent with it. The emergence of Pakistan turned out into a big loss for india as it lost the control over important land routes to the central and the west Asia and also lost the control over strategically important sea lanes in the Arabian sea. In the Nehruvian era when the Indian foreign policy was mainly envisioned by Jawahar Lal Nehru, India chose the path of non-alignment and decided that it would not take sides in the Cold war and became the leader of the Non aligned Movement in 1950's. India remained dependent on UK until the 1960's for its naval requirements- frigates, destroyers, carriers, the aircraft carrier Vikrant (ex-hercules). The indo-soviet friendship came as a break in the 1965 when india decided to induct ex- soviet foxtrot class submarines since the British refused to provide them. During the detente phase of cold war the united states decided to support the Pakistan in the Bangladesh liberation war against india. During the last phase of the war which lasted for the 13 days, an extremely dangerous situation emerged as the USA ordered a carrier battle group, led by the USS Enterprise into the Bay of Bengal. The entry of the enterprise and its implied threat to India reshuffled the Indian strategic thinking about the Indian ocean.

\subsection{Geostrategic Importance of Indian Ocean}

Indian ocean region is of significant importance for a emerging power like india. Their are several reasons behind this claim. The region becomes of critical importance as india heavily rely on the sea lanes of the Indian ocean for its energy import. India's dependence on oil is about 70 percent and the major part of it comes from the gulf region. The sea lanes of the Indian ocean becomes strategically important as more than 80 percrent of the world's seaborne trade in oil transits through the indian ocean with 40 percent passing through strait of hormuz, 35 percent through Bab el mandab strait. The mazor move in last 40-50 years has been towards market self regulation and from that point of view the region becomes of more critical importance for india.

\section{India and the Littoral States}

"You cannot cross the sea merely by standing and staring at the water''-Rabindarnath Tagore [4].

The centrality of india in the region makes it more important to secure its interests in the ocean and with littoral states. India had ancient cultural and trade relations with the countries of indian ocean. Despite having different political history, india had a great influence on the Srilankan culture. Ashoka sent his children to the Ceylon for popularising his dhammas [5]. The buddhist missionaries had profound impact on religious faith of the people of srilanka along with deep impact on cultural traditions. The militant and aggressive form of nationalism india showed in 19th and 20th century, got descended from kautilyan thought and the moderate and rational thought in the Indian freedom struggle descended from the teachings of Lord Buddha which it passed on to the other South Asian and south east asian countries too [6].

Mauritius also had deep religious ties with india where about 48. 54 percent population follow the hindu religion. PM Modi during his visit to Mauritius in 2015 highlighted the deep religious and cultural linkages we share with the indian ocean countries. While facing the fierce competition from china in the region, the indian soft power holds a special place in this power game in the region. India with its 
deep religious, cultural and historical ties with the littoral states runs ahead of china due to its commitment to the peace and belief in democratic values.

\subsection{Through the Dragon's Eye}

"You can change your friends but not neighbours"

Atal Bihari Vajpayee

Through the above saying by the first non congress prime minister of india who completed his full 5 year tenure, we can see how India is surrounded by foes and how important it is to tackle them strategically!

The P8i Poseidon spy planes of Indian navy last year detected the Chinese Amphibian warship Xian-32 in the southern indian ocean, the pictures were clicked when the Chinese warship entered the srilankan waters [7]. It shows how china with its advanced surveillance system is keeping an eye on the indian naval bases in the Andaman Nicobar islands and in southern indian ocean. China gradually increased its marine power with advanced submarines, warships, spying technology. China started besieging india through its "String Of Pearls" policy. The string of pearls is a geopolitical theory which shows the potential Chinese ambitions in the Indian Ocean region. The string of pearls includes the Chittagong port of Bangladesh, Gwadar port in Pakistan and Hambantota port in srilanka. China continuously trying to woo the Indian neighbours through its debt trap policy to the small island nations like srilanka shows its potential intention against india.

\subsection{The Reminder of the History}

In the international relations the realists are referred to as the "children of darkness" but in such a turbulent era of the 21st century where the American hegemony as the sole superpower declined continuously and on the other side the abrupt rise of our neighbour makes it critically important for us to think in realistic terms to protect ourselves from the "Vijigishu" ambitions of our neighbour [8]. The way china objected to Home minister's visit to Arunachal pradesh to celebrate it's 34th statehood day shows that china not only encircling india in the ocean but also want to infringe our lands. According to the satellite pictures clicked in may last year, the military base at Djibouti, set up in 2017 is being modernised into a fully fledged naval base from a logistics support unit. Changes in the distribution of power, historians hold are the main sources of conflict in world politics. The rise of multipolar international politics and declining unipolar American politics has given rise to the new vaccum to be filled by new superior economic and military powerhouses [9]. Earlier in the 1960's when the baton was passed from the United Kingdom to the united states, the transition was quite smooth as the newly independent countries of asia and africa were nowhere in that scenario where united states unilaterally took the decisions and was dominant marine power. But the rise of china and india in the asia has changed the picture in the Indian ocean [10]. The united states under the presidency of Donald Trump tried to encircle china through all the possible ways. The trade war between both the countries, ban on the huwaei $5 \mathrm{~g}$ technology, voicing against china in the multilateral forums, naming the coronavirus as "chinese virus", the trump administration made it clear that they will not left a stone unturned to dent the Chinese image. Both India and United states along with the Japan and Australia reestablished the "Quad" grouping which clearly indicates of getting along with each other in the ocean against the Chinese pursuit of power in the sea lanes.

The chinese hegemonic ambitions that it has become more powerful than its neighbours, mean that Beijing's focus is now on building Chinese century. Although China has every right to claim Asian primacy, others are not obliged to accept it. India standing up to every challenge by the Chinese for example- walking out of the china centric rcep, giving befitting reply to the People's Liberation Army in western sector [11].

\section{Conclusion}

In the concluding analysis, it can be said that the Indian ocean has reemerged as juncture of bitter power rivalry. The hegemonic ambitions of china to be the leader of the world and to turn this asian century into the Chinese century has definitely posed real threats among the other states. China's economic emergence is the main reason behind its hegemonic ambitions which in turn is the result of its growing diplomatic self-confidence and burgeoning structural power [12]. India's stakes in the ocean are very high and very crucial. China's plan to encircle india through the naval bases of the littoral states by giving them huge amount of money and making them to fall into the Chinese debt trap is succeeding [11]. The Chinese interference into the domestic politics of the indian neighbours like myanmar and maldives is also of great concern. India could focus on more actively binding itself to smaller regional states as it already does by sharing Maritime domain awareness and space based surveillance data. Building strategic interdependence would cultivate smaller states to continue co- operation with india. India instead of showing BigBrother attitude should get in tune with the needs and aspirations of the littoral states [13]. Delhi needs to proactively shape its regional environment in tune with its neighbours. The indian soft power will play a crucial role in this. Indian belief in peace and democracy in such turbulent times in international relations help to shape it as a responsible nieghbour and a politically stable and economically sound state which can prove to be beneficial for the small economies of the indian ocean states which mainly run on the tourism sector [14]. Speaking at the first UN General Assembly Session he attended in 2014, Prime minister Narendra Modi stated that India's foreign policy is governed by its old age maxim of "Vashudhaiva Kutumbakam" (The world is a big family), it seems to be coming true as india rightly known as the pharmacy of the world, through his "Vaccine Maitri" initiative is supplying vaccines to its small neighbouring states in the indian ocean. 
Thus, to cope up from the dragon's trap around the indian ocean the indian strategic community should refocus its plans and recentre them around the littoral states [15].

\section{References}

[1] https://www.britannica.com/topic/geopolitics-Information about geopolitics-"Geopolitics refer to political scenario".

[2] https://www.orfonline.org/research/india-rediscovers-theindian-ocean-54684/(India rediscovers the Indian ocean).

[3] Tim Marshall, Prisoners of Geography, 2015, Vol-1, Pp-91, (India is not a nation, nor a country. It is a subcontinent of nationalities-Muhammad Ali Jinnah).

[4] Baylis and smith, Globalization of world Politics, Sixth edition, Pp-428.

[5] S. Jaishankar-The India Way, 2020, Vol-1, Pp-162.

[6] C. Raja. Mohan -Information about the history of the independence ocean. It can be accessed through https://www.india-

seminar.com/2011/617/617_c_raja_mohan.html.
[7] J. N. Dixit, Foriegn Policy of India, Third edition, pp-25, (The militant and aggressive form of nationalism india showed in 19th and 20th century, got descended from kautilyan thought).

[8] The big picture debate "Rajya Sabha tv" ("P8i poseidon spy planes").

[9] V. N. Khanna, International Relations, 2015, Fifth edition, pp12, (Children of darkness).

[10] C. Raja. Mohan, The oxford handbook of foreign policy, 2015, First edition, pp-509.

[11] C. Raja. Mohan -Once upon a asian century (The Indian express editorial -7th July, 2020).

[12] Global Politics - Andrew Heywood, 2011 edition, pp-492.

[13] Does the elephant dance - David M. Malone- India's relations with other countries-pp-215.

[14] The domestic roots of Indian foreign policy - Walter K. Andersen//http://www.jstor.org/stable/30172981.

[15] Explaining Sixty Years of India's Foreign Policy Sumit Ganguly \& Manjeet S. Pardesi /http://dx.doi.org/10.1080/14736480802665162//pp-16. 